DISPATCHES FROM THE FRONT $\boldsymbol{\nabla}$ 



\section{DISPATCHES FROM THE FRONT}

THEOLOGICAL ENGAGEMENTS WITH

\section{THE SECULAR $\boldsymbol{\nabla}$ STANLEY HAUERWAS}

Duke University Press Durham and London 1994 


\section{(C) 1994 Duke University Press}

First printing in paperback, 1995

All rights reserved

Printed in the United States of America on acid-free paper $\infty$

Library of Congress Cataloging-in-Publication Data appear on the last printed page of this book.

Excerpts from Saint Maybe by Anne Tyler

Copyright (C) 1991 by Anne Tyler Modarressi. Reprinted by permission of Alfred A. Knopf, Inc. 
ANN RICE

JIM LANGFORD

ALASDAIR MACINTYRE

TOM SHAFFER 
